\title{
高酸化数金属錯体を用いる陰イオン選択電極
}

\author{
湯 地 昭 夫 $^{1}$
}

\section{Anion-Selective Electrodes Based on Polyvalent Metal Complexes}

\author{
Akio YUCHI \\ ${ }^{1}$ Nagoya Institute of Technology, Gokiso, Showa-ku, Nagoya-shi, Aichi 466-8555
}

(Received 28 September 2005, Accepted 11 November 2005)

\begin{abstract}
The performances of metal complexes and organometalic compounds containing polyvalent metal ions were studied as carriers of liquid membrane anion-selective electrodes from both fundamental and practical view points. 1) The high selectivities of simple dialkyltin(IV) compounds to phosphate and to $\alpha$-hydroxycarboxylates were ascribed to formation of partially hydrolyzed polynuclear complexes, where these anions interacted with two Sn(IV) centers and were shielded from the solvent by alkyl groups projected from $\mathrm{Sn}(\mathrm{IV})$. This is the first evidence that the self-assembling reactions of a carrier and a sample anion create novel selectivities in potentiometry with liquid membrane anion-selective electrodes. 2) Tetraphenylporphine ( $\left.\mathrm{H}_{2} \mathrm{tpp}\right)$ complexes of $\mathrm{Ti}(\mathrm{IV}), \mathrm{V}(\mathrm{IV}), \mathrm{Zr}(\mathrm{IV}), \mathrm{Hf}(\mathrm{IV}), \mathrm{Nb}(\mathrm{V})$, and $\mathrm{Ta}(\mathrm{V})$ were prepared and evaluated as carriers of ISEs. Among a series of $\mathrm{Zr}(\mathrm{IV})$-tetraphenylporphine complexes, cationic dimers, $\left(\left[\mathrm{Zr}_{2}(\mathrm{OH})_{3}(\mathrm{tpp})_{2}\right], \mathrm{X}\right)$, showed the selectivity characteristic of the ion-exchange process. The response was smaller for the cationic dimers containing $\mathrm{X}^{-}$of higher lipophilicities. In contrast, neutral monomers, $\left[\mathrm{ZrX}_{2}(\mathrm{tpp})\right]$, showed the selectivity indicating contribution of ligand-exchange reactions. Among the neutral monomers, $\left[\mathrm{ZrCl}_{2}(\mathrm{tpp})\right]$ was easily hydrolyzed to give $[\mathrm{Zr}(\mathrm{OH}) \mathrm{Cl}(\mathrm{tpp})]$, which showed an appreciable response to carboxylates. The response slowly deteriorated by replacement of chloride with hydroxide but was recovered in a reversible manner by conditioning the membrane with concentrated hydrochloric acid. The monomer, $\left[\mathrm{Zr}(\mathrm{OH})_{2}(\mathrm{tpp})\right]$, was proposed as a carrier of an excellent citrate-selective electrode. 3) The neutral dimer $\left[\mathrm{Nb}_{2} \mathrm{O}_{3}(\mathrm{tpp})_{2}\right]$ rapidly reacted with phosgene to give $[\mathrm{NbOCl}(\mathrm{tpp})]$. This reaction was successfully applied to the spectrophotometric monitoring of the spontaneous formation of phosgene in chlorinated hydrocarbons. 4) Potentiometric performances were briefly described about the $\mathrm{Zr}(\mathrm{IV})$-dodecyliminodiacetate complex, the Ge(IV)-nitrilotriphenol complex, and naphthylboronic acid. All these results were discussed in terms of multi-points recognition, self-assembly, charges on carriers, additives, conditioning and life-time.
\end{abstract}

Keywords : ion-selective electrode; carrier; anion; citrate ; two-phase reaction.

\section{1 はじめに}

イオン選択電極による電位差測定は, 妨害物質を分離・ 除去することなく，また試料溶液の濁りや着色に妨害され ることなく，迅速かつ簡便に広いダイナミックレンジで目 的物質の定量を行うことができ, 自動化・オンラインモニ

\footnotetext{
${ }^{1}$ 名古屋工業大学大学院工学研究科しくみ領域：466-8555 愛知 県名古屋市昭和区御器所町
}

タリングにも適していることから，様々な分野で利用され ている。電解質イオンを中心に陽イオンについては技術が ほほ成熟しているのに対して，陰イオンについては現在も 開発が進められているところである。イオンの認識に用い られるキャリヤーとの相互作用が陰イオンの場合には陽イ オンの場合ほど強くないため, 膜相への輸送に伴う脱水和 の不利を克服することができず，特徴的な選択性を生み出 すことは困難とされてきた。しかしながら，近年の超分子 
化学分野の進歩に伴って ${ }^{12)}$, 静電相互作用に加えて水素 結合やファンデルワールスカなどの弱い相互作用を組み合 わせることによって, 新規な選択性の発現が報告されるよ うになってきだ).

陽イオンの認識に駆使されているルイスの酸塩基相互作 用は陰イオンの認識にも有効な強い相互作用であり, 1980 年代中ごろから有機スズ化合物や金属ポルフィリン 錯体がキャリヤーとして検討され，特徵的な選択性が報告 されてきた，本稿では，このタイプのキャリヤーについて これまでに得られている情報を整理した上で, 著者らが最 近に得た知見をまとめてみることにする.

\section{$1 \cdot 1$ 多点相互作用と自己集合}

超分子化学の進歩の中で, 構造性を有する陰イオンに対 して，相補的な骨格中に複数の水素結合サイトを含むよう に高度に分子設計された多点認識ホストが合成され，優れ た選択性が報告されるようになっている(1) 3). 同様に，一 つのホストの中に複数のルイス酸サイトを導入することに より, 反応性や選択性を向上させようとする試みが検討さ れてきた。これらの化合物の一部は, 陰イオン選択電極キ ヤリヤーとしての性能も検討され，例えば，マーキュロカ ルボランドが塩化物イオン ${ }^{4)}$, 有機スズ化合物がリン酸 オンのキャリヤーとして提案されている5. また，ルイス の酸塩基相互作用と水素結合とを組み込んだウラニルーサ ロフェン錯体がリン酸イオン選択電極として提案されてい $ろ^{6}$.

これに対して，分子認識におけるもう一つの戦略として の自己集合的な反応に関しては, 分光学的な計測に巧妙に 利用した報告があるのに対しで，イオン選択電極に積極 的に利用した例はないようである。

\section{$1 \cdot 2$ ニュートラルキャリャーとチャージドキャリャー}

イオン選択電極で応答の要となるキャリヤーは, その電 荷によってニュートラルキャリヤー及びチャージドキャリ ヤーに分類される．有機化合物の場合にはその区別は明白 であるのに対して，有機金属化合物や金属錯体の場合には 必ずしも明確ではない。例えば有機スズ（IV）化合物や 3 価金属イオンのポルフィリン錯体については, 式( 1 ) (4) で示されるように, いずれの機構による応答も原理 的に可能である ${ }^{899}$.

\section{有機スズ (IV) 化合物}

$$
\begin{aligned}
& {\left[\mathrm{R}_{3} \mathrm{SnX}\right]+\mathrm{Y}^{-}=\left[\mathrm{R}_{3} \mathrm{SnY}\right]+\mathrm{X}^{-}} \\
& {\left[\mathrm{R}_{3} \mathrm{SnX}\right]+\mathrm{Y}^{-}=\left[\mathrm{R}_{3} \mathrm{SnXY}\right]^{-}}
\end{aligned}
$$

金属 (III)-ポルフィリン（tpp）錯体

$$
\begin{aligned}
& {[\mathrm{Co}(\mathrm{tpp}) \mathrm{Cl}]+\mathrm{NO}_{2}{ }^{-}=\left[\mathrm{Co}(\mathrm{tpp})\left(\mathrm{NO}_{2}\right)\right]+\mathrm{Cl}^{-}} \\
& {\left[\mathrm{Co}(\mathrm{tpp})\left(\mathrm{NO}_{2}\right)\right]+\mathrm{NO}_{2}{ }^{-}=\left[\mathrm{Co}(\mathrm{tpp})\left(\mathrm{NO}_{2}\right)_{2}\right]^{-}}
\end{aligned}
$$

式（1）及び（3）では，中心金属にあらかじめ配位し ている陰イオン（結合除イオン）がサンプル陰イオンによ って置換され，結合イオンが解離して生成する陽イオン性 化学種を想定して, チャージドキャリヤーと分類される. この置換反応には, 結合陰イオン及びサンプル陰イオンが 共に配位能力を有する場合の配位子交換反応から，両方と もに配位能力がない場合の単純なイオン交換反応までのい ろいろな場合があると考えられる。一方，式（2）及び （4）では，陰イオンが中性錯体に付加的に配位して陰イ オン性の錯体を形成しており，ニュートラルキャリヤーに 分類できる.この場合, 水や有機溶媒などの中性配位子を 考慮から外せば，見掛け上は金属錯体や有機金属化合物の 配位数が増えることになる。このように有機金属化合物や 金属錯体と陰イオンとの相互作用の仕方には，ある種の多 様性があると理解されている.

\section{$1 \cdot 3$ 添加剤}

イオン選択電極では選択性を向上したり，応答性を改善 したりするために，添加剤が用いられる，チャージドキャ リヤーを用いた陰イオン選択電極の場合に疎水性の陰イオ ンを含む塩（アニオン排除剤と呼ばれる）を添加すると， イオン交換的な応答機構は抑制されるために，その他の相 互作用の寄与が相対的に強調されて選択性は向上する。一 方，ニュートラルキャリヤーの場合にはサンプル陰イオン との反応で生成する複合体が陰イオン性となる。このた め, 疎水性陽イオンを含む塩 (カチオン添加剂と呼ばれる) を添加すると複合体の電荷が効果的に中和されて，応答性 が改善すると報告されている ${ }^{10111}$ ．応答機構を判定するた めに，これらの添加剤の影響が通常は検討されているが， その結論は必ずしも明確でない場合もある。

ごく最近になって，金属ポルフィリン錯体をキャリヤー とする系に脂溶性の陰イオンを添加剂として加えると, こ れを対イオンとする陽イオン性二量体が生成すること, 更 に，サンプル陰イオンによって二量体構造の開裂が引き起 こされる際にスーパーネルンスト応答が観測されることが 明らかにされた ${ }^{12) ~ 15)}$. また，金属ポルフィリン錯体を高 分子に共有結合で固定することにより，二量体の生成を抑 制して，イオン交換的な機構を排除し，中心金属固有のル イス酸特性を十分に発現させることができる ${ }^{16)}$.

以上のように，ルイス酸を含む液膜型イオン選択電極に よる陰イオンの計測では, 結合陰イオン, 添加剤中の陰イ オン, サンプル陰イオン, 内部液から供給される陰イオン (多くの場合に塩化物イオン) 及び水由来の水酸化物イオ ンが膜中でのキャリヤーの溶存状態に影響を及ぼしてい る. 液膜型電極の検出限界を低減する試みの中で，膜を挟 んだ二つの水相間における 2 種のイオンの濃度勾配につ いてかなりの議論がなされているが ${ }^{1718)}$ ，これらすべての 


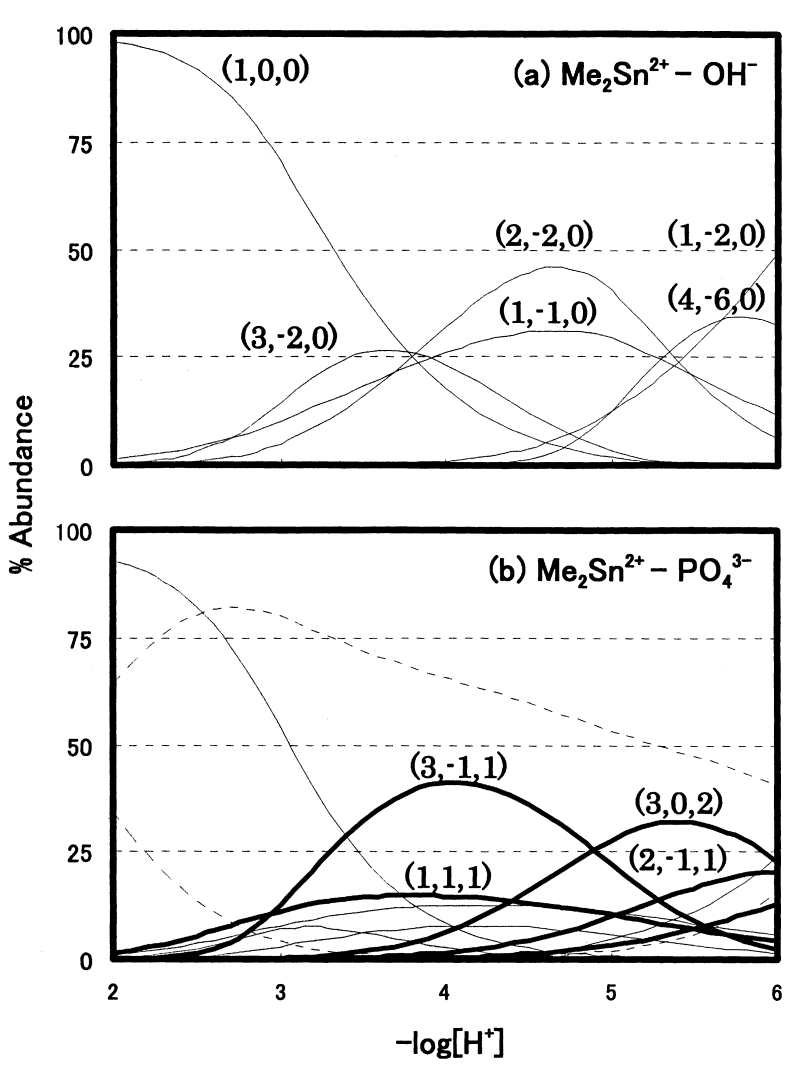

Fig. 1 Distribution of species as a function of $-\log \left[\mathrm{H}^{+}\right]$in $\mathrm{Me}_{2} \mathrm{Sn}^{2+}-\mathrm{OH}^{-}$(a) system and $\mathrm{Me}_{2} \mathrm{Sn}^{2+}$ $\mathrm{PO}_{4}{ }^{3-}$ (b) system at $25^{\circ} \mathrm{C}$ and at $1.0 \mathrm{~mol} \mathrm{dm}{ }^{-3} \mathrm{KNO}_{3}$

$C_{\mathrm{Sn}}: 3 \times 10^{-3} \mathrm{~mol} \mathrm{dm}^{-3}, C_{\mathrm{P}}: 3 \times 10^{-3} \mathrm{~mol} \mathrm{dm}^{-3}$. Thick curves: dimethyltin(IV) species complexed with phosphate; thin curves: hydrolyzed dimethyltin(IV) species; broken curves: phosphate species. See eq. (5) for each species expressed by $(p, q, r)$.

関係を定量的に記述するに至っていないのが現状である.

\section{$1 \cdot 4$ コンディショニングと寿命}

固体膜型とは異なって, 液膜型のイオン選択電極では, 製膜直後からサンプルイオンに対する電位応答が得られる 場合と，使用前に所定の溶液でコンディショニングを行わ ないと応答が得られない場合とがある。しかしながら， 「このコンディショニングの間に化学的にどのようなこと が進行して応答が得られようになるのか？」に対して明確 な説明がなされている例はない.

固体膜型と比べて液膜型電極は寿命の点でも劣るとされ てきた。応答が劣化する原因としては，脂溶性が不十分な ためにキャリヤー・添加剤・膜溶媒が試料溶液中に徐々に 溶け出す, キャリヤー自体が不安定であり時間の経過とと もに分解する，などが挙げられている．前者に対する対策 として, 膜溶解性の高い物質を用いる, あるいは, これら の物質を支持体に化学的に固定する ${ }^{19220)}$ な゙の試みがなさ れている。これに対して, 後者については推測に過ぎず,
実際にキャリヤーの分解を検証したり，その対策が立てら れたりした例はない。

\section{2 有機スズ化合物}

\section{$2 \cdot 1$ 自己集合によるリン酸選択性の発現}

$1 \cdot 1$ で述べたように，複数のスズ (IV) を一つのキャリ ヤーの中に組み込むことにより, リン酸イオン選択性の発 現することが報告されてきだ)。一方で，かなり以前にロ シアのグループにより，単純なジアルキルスズ化合物がリ ン酸やヒ酸イオン選択電極のキャリヤーとして提案さ れ21)，後にジベンジル化合物 $\left(\mathrm{Bz}_{2} \mathrm{Sn}^{2+}\right)$ が最も優れてい ると報告された ${ }^{22)}$. しかし，なぜこのような単純な化合物 でリン酸イオンに対する選択性が発現するのかという理由 は明らかでなかった。

著者らは，ジメチルスズイオン $\left(\mathrm{Me}_{2} \mathrm{Sn}^{2+}\right)$ を水溶性の 類縁体として，リン酸やヒ酸イオンとの水溶液中での錯形 成平衡を $\mathrm{pH}$ 滴定法によって解析してみた ${ }^{23)}$. 得られた平 衡定数を用いて算出した各化学種の存在比を $-\log \left[\mathrm{H}^{+}\right]$の 関数として Fig. 1 に示す。なお，図中の $(p, q, r)$ は次式 によって生成する化学種を表す.

$$
\begin{aligned}
& p\left(\mathrm{Me}_{2} \mathrm{Sn}\right)^{2+}+q \mathrm{H}^{+}+ r \mathrm{~A}^{n^{-}}= \\
& {\left[\left(\mathrm{Me}_{2} \mathrm{Sn}\right)_{p} \mathrm{H}_{q} \mathrm{~A}_{r}\right]^{(2 p+q-n r)+} }
\end{aligned}
$$

ジメチルスズイオンは弱酸性溶液中で主として $(2,-2,0)=$ $\left[\left(\mathrm{Me}_{2} \mathrm{Sn}\right)_{2}(\mathrm{OH})_{2}\right]^{2+}$ のような二核の化学種として存在する のに対して $\{$ Fig. 1 (a)\}, リン酸イオンが共存すると, $(3,-1,1)=\left[\left(\mathrm{Me}_{2} \mathrm{Sn}\right)_{3}(\mathrm{OH})_{2}\left(\mathrm{HPO}_{4}\right)\right]^{2+}$ や $(3,0,2)=$ $\left[\left(\mathrm{Me}_{2} \mathrm{Sn}\right)_{3}(\mathrm{OH})_{2}\left(\mathrm{HPO}_{4}\right)_{2}\right]$ のような三核の化学種を生成す る $\left\{\right.$ Fig. 1（b) \}. Simonのグループは, Kryptofix $222^{\circledR}$ 共 存下の $\mathrm{CDCl}_{3}$ 中で塩化ジオクチルスズ (IV) とリン酸水素 イオンとの反応を ${ }^{119} \mathrm{Sn}$-核磁気共鳴法 (NMR) で追跡し, 電気化学的活性種を同定しようと試みた ${ }^{24)}$. 論文には記載 されていないが，表の数值を用いて実際にモル比法プロッ トを行ってみると，1:3で屈曲点を示しており（Fig. 2)， 正に三核の化学種の生成を支持する。 $(3,0,2)$ の化学種は 全体として中性であり，いわゆるコンディショニングと呼 ばれる過程で，このような電気化学的活性種が膜中に形成 されると考えられ，1・4で提起した問いに対する一つの答 えを与える。この電極では，膜中でのキャリヤー濃度とし て通常より 1 けた濃い $18 \%$ が処方されているが22)，これ も多核の化学種の生成を有利にするためと説明することが できる。

この中性三核錯体には Fig. 3 （a，b）のように二つの構 造が考えられる。実際にキャリヤーに用いられるジベンジ ル誘導体について対応する三核種の構造を MOPACによ り最適化すると $\{$ Fig. 3 (c, d ) \}, いずれの構造をとる場 
合でもベンジル基が効果的にリン酸イオンを外部の水から 遮蔽していることが分かる.このことも，この化学種が電 気化学的に活性であることを裏付ける.

以上のようにして，1・1で述べた自己集合的な反応によ

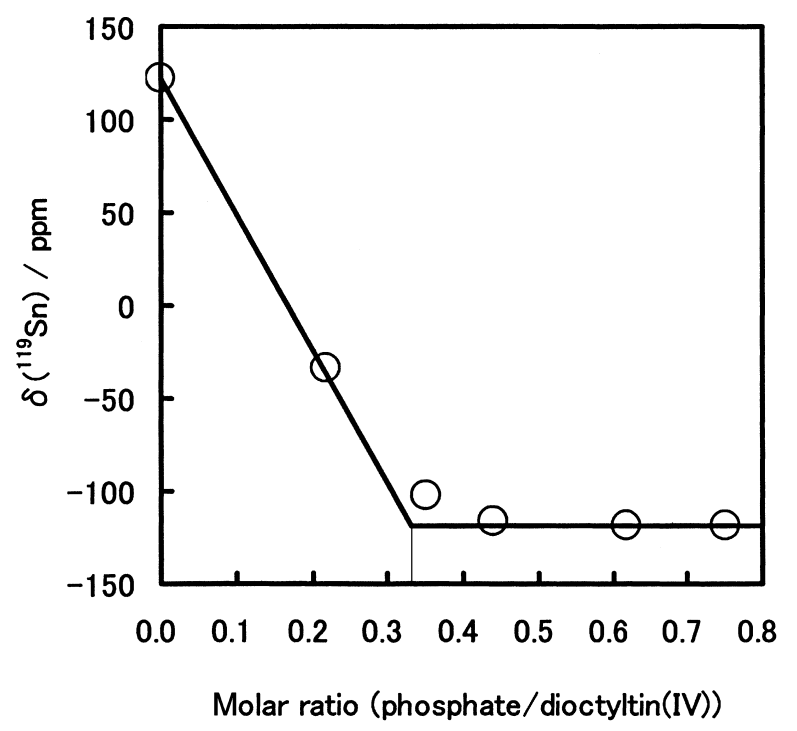

Fig. 2 Molar ratio plot on the reaction of dioctyltin(IV) dichloride with $\mathrm{K}_{2} \mathrm{HPO}_{4}$ in the presence of Kryptofix222 in $\mathrm{CDCl}_{3}$

Data were taken from ref. 24
る多点認識が本系で正に起こり，その結果として選択的電 位応答が発現していることを明確に示すことができた。

\section{$2 \cdot 2 \alpha$-ヒドロキシカルボン酸選択性の発現}

同じジベンジル化合物がクエン酸イオン選択性電極のキ ヤリヤーとしても提案されている ${ }^{25)}$. そこで, クエン酸及 びその部分構造に対応する一連のカルボン酸とジメチルス ズイオンとの錯形成平衡を同様に検討した ${ }^{26)}$. ジメチルス ズ及びカルボン酸の酸塩基反応だけが起こると仮定した場 合に各実測点に対して期待される $\mathrm{pH}$ の值と実測值のズレ $(\Delta \mathrm{pH})$ を Table 1 に示す. $\alpha$-ヒドロキシカルボン酸（グ リコール酸，乳酸，リンゴ酸，クエン酸）の場合の $\Delta \mathrm{pH}$ は他に比べて有意に大きく， $\alpha$ 位に水酸基があると錯形成 反応がより顕著に進むことが明らかとなった。

クエン酸及びリンゴ酸の系は多くの酸塩基反応が平行し て起こるために解析が困難であったが，酢酸，ヒドロアク リル酸，グリコール酸及び乳酸などのモノプロトン酸 （Hma で示す）の系では錯形成平衡を解析することができ た．酢酸及びグリコール酸を含む系での分布曲線を Fig. 4 に示す. 図中の $(p, q, r)$ は次式によって生成する化学種 を表す。

$$
p\left(\mathrm{Me}_{2} \mathrm{Sn}\right)^{2+}+q \mathrm{H}^{+}+r \mathrm{ma}^{-}=
$$

$$
\left[\left(\mathrm{Me}_{2} \mathrm{Sn}\right)_{p} \mathrm{H}_{q}(\mathrm{ma})_{r}\right]^{(2 p+q-r)+}
$$

(a)<smiles>C[Si](C)(C)OP(=O)(O)O[Si]1(C)O[Si](C)(C)O[Sn](C)(C)O1</smiles>

(c)

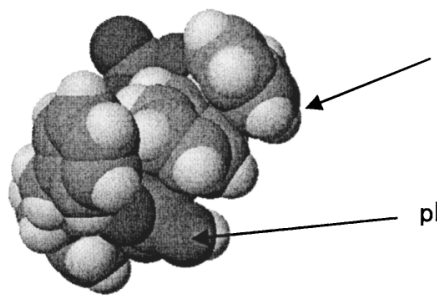

(b)

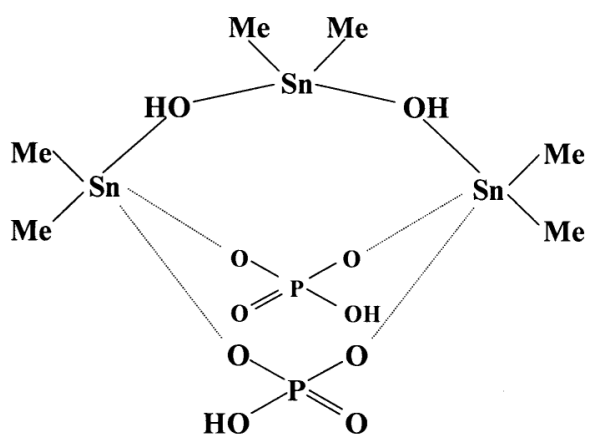

(d)

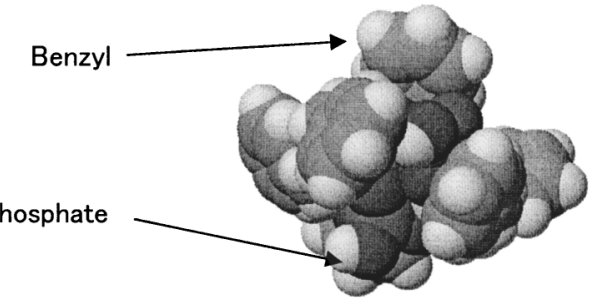

Fig. 3 Possible structures for $\left[\left(\mathrm{Me}_{2} \mathrm{Sn}\right)_{3}(\mathrm{OH})_{2}\left(\mathrm{HPO}_{4}\right)_{2}\right]$ in the aqueous phase $(\mathrm{a}, \mathrm{b})$ and PM3-optimized structures for $\left[\left(\mathrm{Bz}_{2} \mathrm{Sn}\right)_{3}(\mathrm{OH})_{2}\left(\mathrm{HPO}_{4}\right)_{2}\right]$ as an electroactive species in the membrane phase $(\mathrm{c}, \mathrm{d})$ 
Table $1 \quad \Delta \mathrm{pH}$ values on reactions of $\mathrm{Me}_{2} \mathrm{Sn}^{2+}$ with some carboxylic acids

\begin{tabular}{lcc}
\hline \multirow{2}{*}{ Carboxylic acid } & \multicolumn{2}{c}{$\Delta \mathrm{pH}$} \\
\cline { 2 - 3 } & {$[1: 1]$} & {$[1: 2]$} \\
\hline acetic acid & 0.065 & 0.066 \\
hydracrylic acid & 0.034 & 0.029 \\
succinic acid & 0.034 & 0.060 \\
propanetricarboxylic acid & 0.125 & 0.048 \\
glycolic acid & 0.361 & 0.346 \\
lactic acid & 0.406 & 0.323 \\
malic acid & 0.323 & 0.294 \\
citric acid & 0.703 & 0.135 \\
\hline $10^{3} C_{\mathrm{Sn}} / \mathrm{mol} \mathrm{dm}$ & $: 3[1: 1], 2[1: 2] ; 10^{3} C_{\text {acid }} / \mathrm{mol} \mathrm{dm}^{-3}: 3$ \\
{$[1: 1], 4[1: 2]$.} &
\end{tabular}

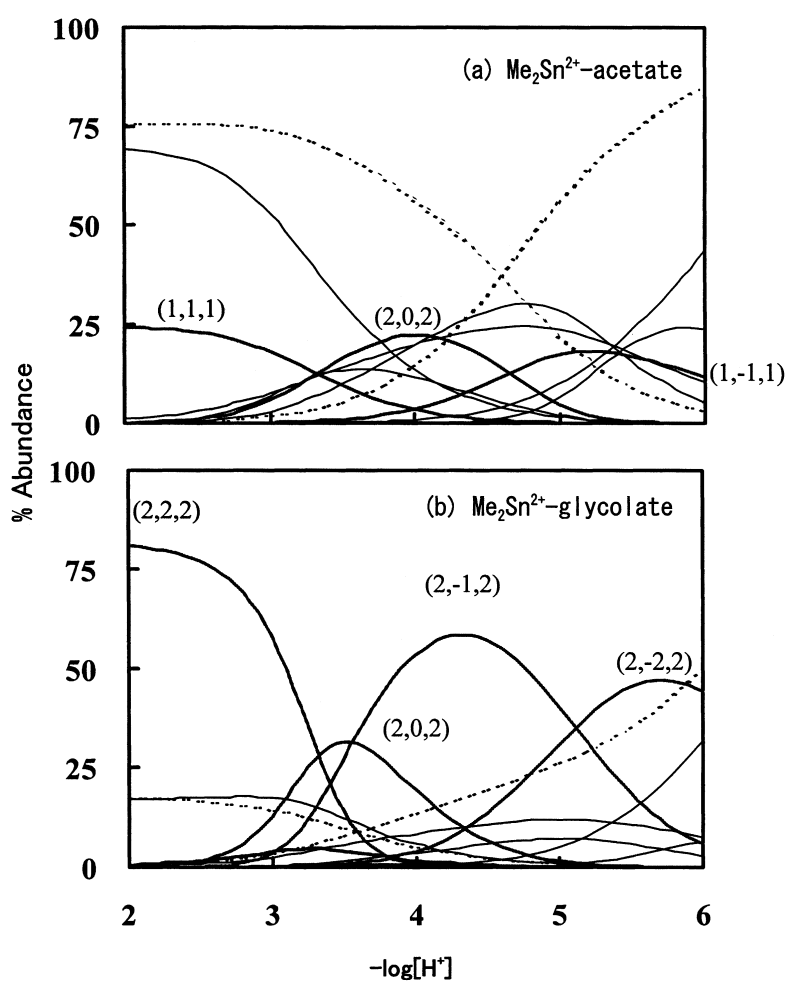

Fig. 4 Distribution of species as a function of $-\log \left[\mathrm{H}^{+}\right]$in $\mathrm{Me}_{2} \mathrm{Sn}^{2+}$-acetate (a) system and $\mathrm{Me}_{2} \mathrm{Sn}^{2+}$ glycolate (b) system

$C_{\mathrm{Sn}}: 3 \times 10^{-3} \mathrm{~mol} \mathrm{dm}^{-3}, C_{\mathrm{ma}}: 3 \times 10^{-3} \mathrm{~mol} \mathrm{dm}^{-3}, 1.0$ mol dm ${ }^{-3} \mathrm{KNO}_{3}, 25^{\circ} \mathrm{C}$. Thick curves: dimethyltin(IV) species complexed with carboxylates; thin curves: hydrolyzed dimethyltin(IV) species; broken curves: carboxylate species. See eq. (6) for each species expressed by $(p, q, r)$.

酢酸の系では最大でも $25 \%$ 程度しか錯体を生成しない のに対して \{Fig. 4（a)\}，グリコール酸の系では pH 2 で 既に $80 \%$ が $(2,2,2)=\left[\left(\mathrm{Me}_{2} \mathrm{Sn}\right)_{2}(\mathrm{Hma})_{2}\right]^{4+}$ として錯体を形 成しており, $\mathrm{pH}$ の上昇とともに 4 段階で酸解離して弱酸 性では $(2,-2,2)$ を生成することが分かった $\{$ Fig. 4 (b) $\}$.<smiles></smiles>

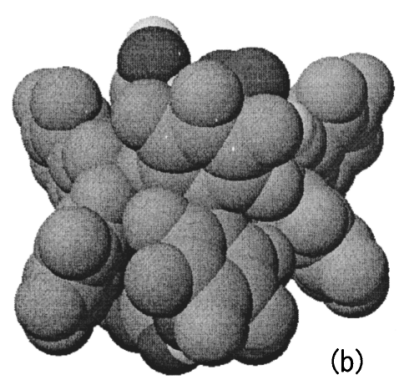

Fig. 5 Possible structure for $\left[\left(\mathrm{Me}_{2} \mathrm{Sn}\right)_{2}\left(\mathrm{H}_{-1} \mathrm{ga}\right)_{2}\right]$ in the aqueous phase (a) and PM3-optimized structure for $\left[\left(\mathrm{F}_{5}-\mathrm{Bz}\right)_{2} \mathrm{Sn}\right]_{2}\left(\mathrm{H}_{-1} \mathrm{cit}\right)_{2}$ as an electroactive species in the membrane phase $(\mathrm{b})$

この脱プロトン反応には配位水分子起因のものとグリコー ル酸の水酸基起因のものが考えられるが， ${ }^{1} \mathrm{H}-\mathrm{NMR}$ やメス バウアー分光などの研究の結果を考慮すると, 後者と考え られる. カルボン酸の $\alpha$ 位のヒドロキシル基が脱プロト ン化して二つのスズを架橋するような構造 $\left\{\left[\left(\mathrm{Me}_{2} \mathrm{Sn}\right)_{2}\left(\mathrm{H}_{-1} \mathrm{ma}\right)_{2}\right]\right.$, Fig. 5 (a) $\}$ が二つ組み合わさる ことによって, 全体として安定化を受けると考えられ る ${ }^{27)}$ ・この骨格でジベンジル誘導体について計算機シミュ レーションを行うと, 同様にベンジル基が効果的に $\alpha$-ヒ ドロキシカルボン酸を外部の水から遮蔽していることが分 かる $\{$ Fig. 5 (b) \}.

ジアルキルスズ化合物は固いルイス酸であるとともに， 錯形成反応を起こす際に重合度や加水分解の程度を柔軟に 変化させる能力を有しているために，これらの㓌イオンと 脂溶性で安定な化学種を形成することができ, 高い選択性 が発現すると考えられる。

\section{$2 \cdot 3$ フッ素化によるルイス酸性の向上}

ジベンジルスズ化合物で，ベンゼン環のパラ位に電子求 引性の置換基を導入するとリン酸イオンに対する検出限界 が向上するのに対して，電子供与性の置換基を導入すると 劣化することが報告された ${ }^{25)}$.そこでベンゼン環のすべて をフッ素で置換した臭化ビス (ペンタフルオロベンジル) ス ズ (IV) を合成し，その性能をこれまでの一連の化合物と 比較した ${ }^{28)}$.

この新規化合物は, pH 3 付近でリン酸イオンに対し て $70 \mathrm{mV} /$ decade と大きな電位応答勾配を持つなど特徵 的な応答選択性を示した（Fig. 6)。しかしながら，その 応答は膜中でのキャリヤー濃度が 5 mass \% の場合に 2 日， 13 mass\% の場合に 1 週間程度で消失し，実用に耐えるだ けの安定性に久けていた。

なお，既報のベンジル及び $p$-フルオロベンジル化合物 の性能について追試を行ったが（Fig. 7)，原著論文で提 


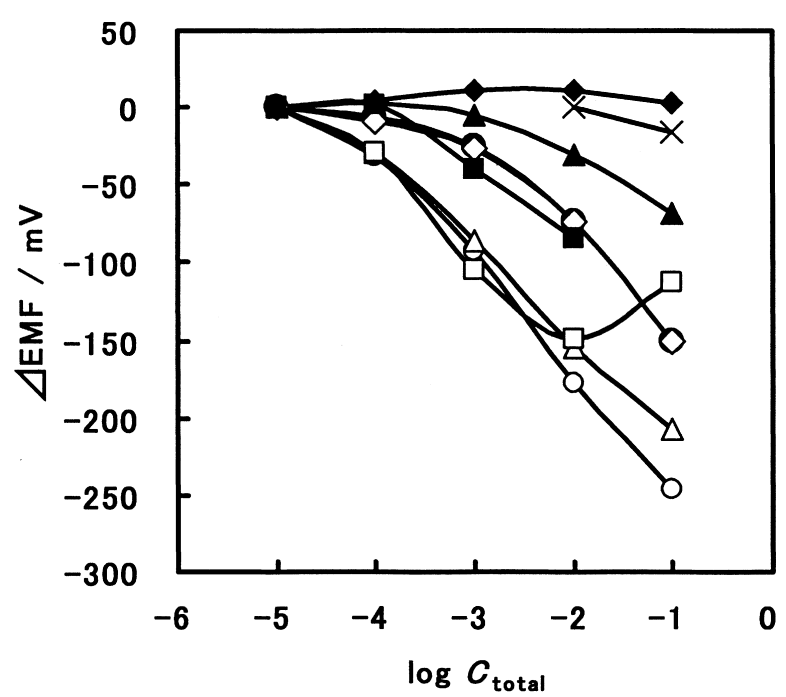

Fig. 6 Potential responses of bis(pentafluoro)benzyltin(IV) dichloride to common anions

(○) $\mathrm{H}_{2} \mathrm{PO}_{4}{ }^{-},(\square) \mathrm{F}^{-},(\triangle) \mathrm{SCN}^{-},(\diamond) \mathrm{Cl}^{-},(\bigcirc) \mathrm{Br}^{-}$,
(घ) $\mathrm{NO}_{2}{ }^{-},(\Delta) \mathrm{NO}_{3}{ }^{-},(\diamond) \mathrm{ClO}_{4}{ }^{-},(\times) \mathrm{SO}_{4}{ }^{2-}$

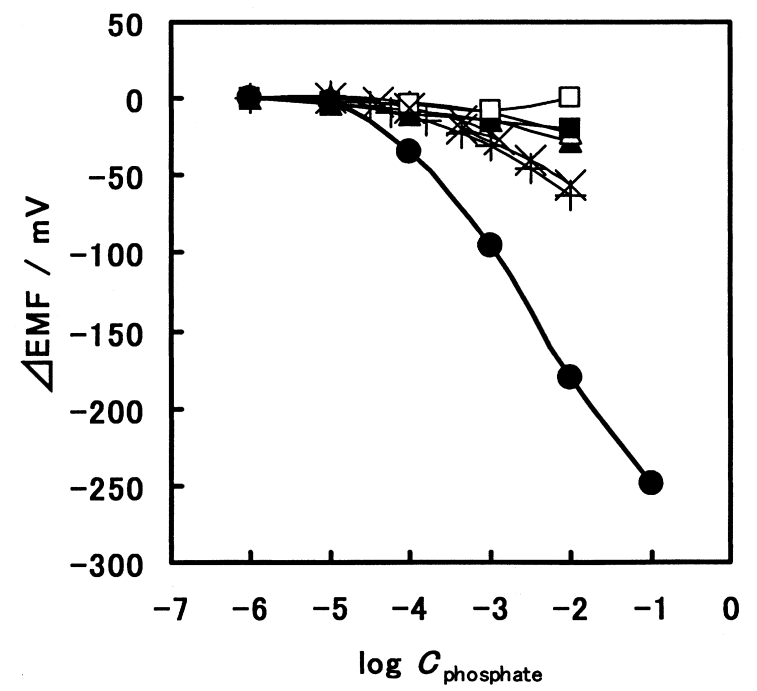

Fig. 7 Potential responses of dibenzyltin(IV) compounds to phosphate

Carrier: (O) $\left[\left(\mathrm{F}_{5}-\mathrm{Bz}\right)_{2} \mathrm{SnBr}_{2}\right] ;\left(\mathbf{\square}, \square,+{ }^{25)}\right)[(\mathrm{F}-$ $\left.\mathrm{Bz})_{2} \mathrm{SnCl}_{2}\right] ;\left(\boldsymbol{\Delta}, \triangle, \times^{22)}\right)\left[(\mathrm{Bz})_{2} \mathrm{SnCl}_{2}\right] . \quad \mathrm{pH}$ :

А) $3 ;(\square, \triangle,+, \times) 7$

Table 2 Summary of porphyrin complexes used as carriers of ISEs

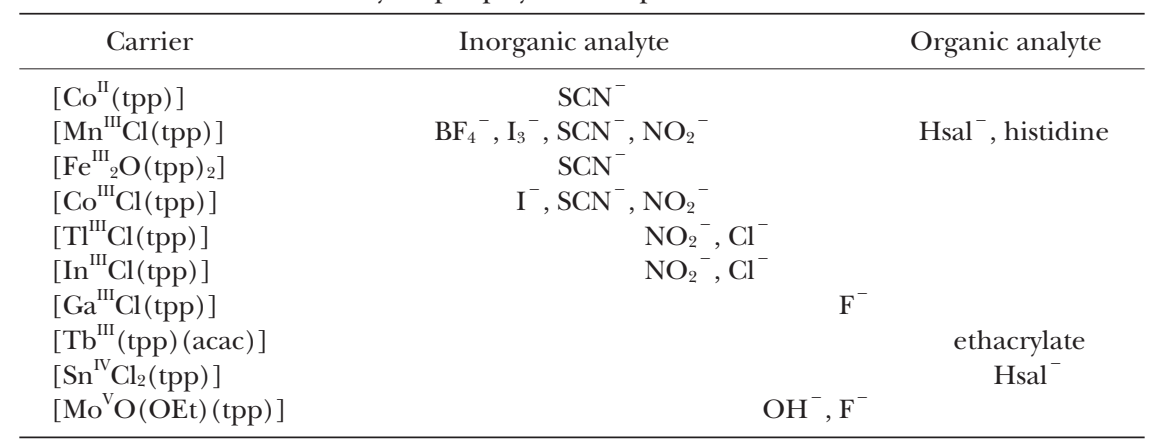

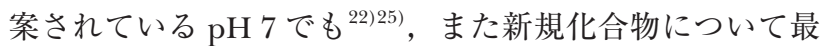
適化した条件である $\mathrm{pH} 3$ でも，リン酸イオンに対する応 答はほとんど見られなかった。原著論文の性能が再現でき なかった理由は不明である。

\section{3 高酸化数金属-ポルフィリン錯体}

金属ポルフィリン錯体は，金属-配位子間の結合が一般 に強固である一方，アピカル位で中心金属イオンとの相互 作用が期待でき，また錯体全体の脂溶性も高いので，陰イ オン選択電極のキャリヤーとして適している. Simon ら による Co (III) - コビル酸錯体の先駆的な研究以来 ${ }^{29)}$, 種々の金属ポルフィリン錯体の性能が検討されてきた ${ }^{12)}$ 16)30) 51). これまでに報告されているサンプル陰イオンと その中心金属との関係を Table 2 に示す. 中心金属が硬 いほど，硬い陰イオンに強く応答する傾向が見られる. 1999 年の時点で，酸化数 4 については Sn(IV)錯体 ${ }^{48)}{ }^{49)}, 5$ については $\mathrm{Mo}(\mathrm{V})^{50)}$ 錯体の応答挙動が報告されていた。
著者らは新たな選択性を期待して, その他の高酸化数金属 錯体の性能評価に着手した。

\section{$3 \cdot 1$ 金属 (IV) 錯体間の比較}

酸化数が 4 の金属イオンとテトラフェニルポルフィン （ $\mathrm{H}_{2} \mathrm{tpp} ）$ を反応させ，シリカゲルクロマトなどで精製す ることにより，比較的イオン半径の小さい $\mathrm{V}(\mathrm{IV})$ 及び $\operatorname{Ti}(\mathrm{IV})$ については $[\mathrm{MO}(\mathrm{tpp})]$ 型の錯体を，イオン半径の 大きい $\mathrm{Zr}(\mathrm{IV})$ 及び $\mathrm{Hf}(\mathrm{IV})$ については $\left[\mathrm{MA}_{2}(\mathrm{tpp})\right]$ 型（A： $\mathrm{OH} ， \mathrm{Cl}$ など）の錯体を合成した ${ }^{52)}$ 。後者の組成は $\left[\mathrm{SnCl}_{2}(\mathrm{tpp})\right]$ と同一であるが, $\mathrm{Sn}$ 錯体では二つの補助配 位子がポルフィリン環を挟んで上下に位置するのに対し て，Zr 及び Hf 錯体では同じ側に位置する点で構造上の違 いがある。

いずれの錯体も $\mathrm{pH}$ に対して広い範囲で電位応答を示し たが (Fig. 8), 次の 2 点で挙動に差が見られた。 (1)アル カリ性領域で, [MO(tpp)] 型はカチオン応答を示すのに 


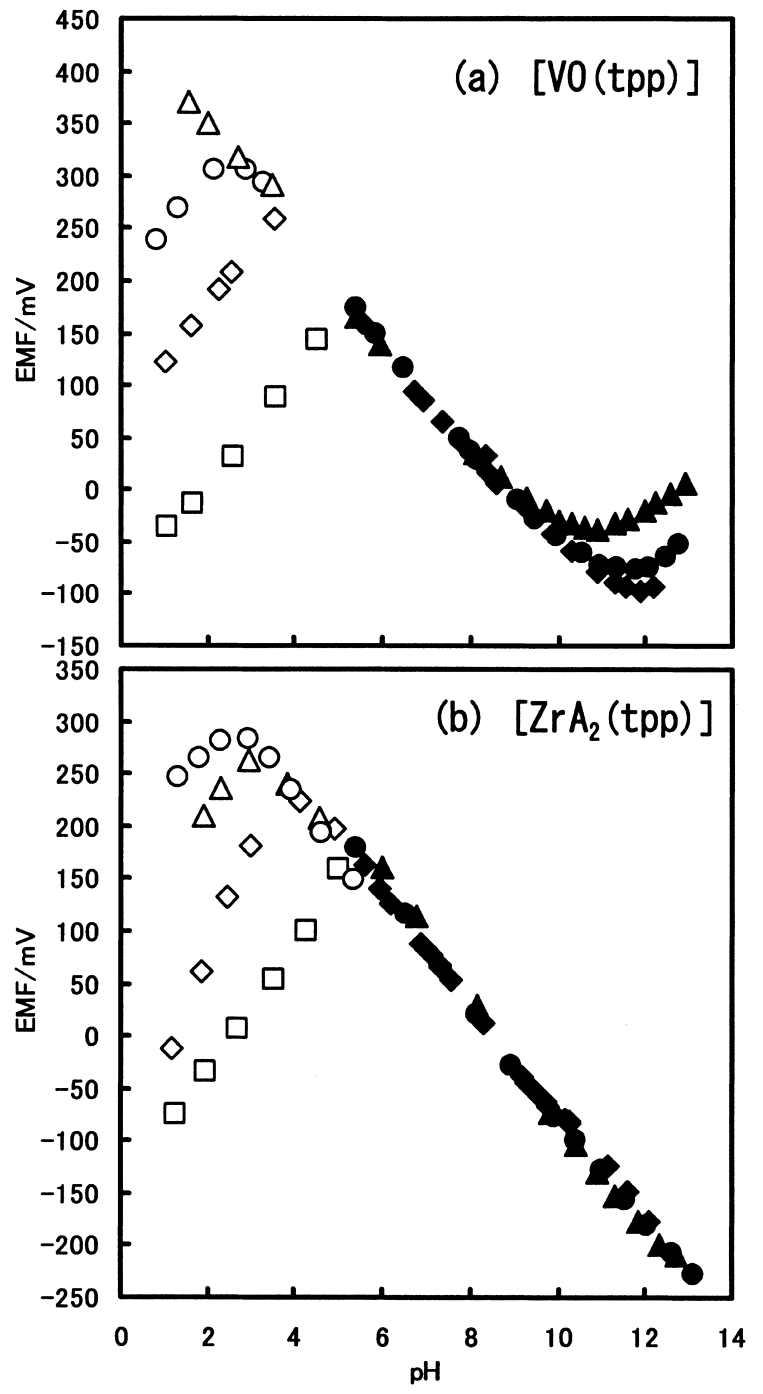

Fig. 8 Effects of $\mathrm{pH}$, acid, and alkali on the potential responses of $[\mathrm{VO}(\mathrm{tpp})]$ - and $\left[\mathrm{ZrCl}_{2}(\mathrm{tpp})\right]$-based ISEs Acid: $(\triangle) \mathrm{H}_{3} \mathrm{PO}_{4},(\bigcirc) \mathrm{HCl},(\diamond) \mathrm{HNO}_{3},(\square) \mathrm{HClO}_{4}$;

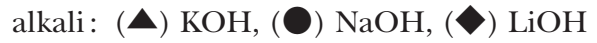

対して, $\left[\mathrm{MA}_{2}(\mathrm{tpp})\right]$ 型は示さなかった. (2)いずれも酸性 領域でアニオン応答を示したが, $[\mathrm{MO}(\mathrm{tpp})]$ 型の選択性 は $\mathrm{ClO}_{4}{ }^{-}>\mathrm{NO}_{3}{ }^{-}>\mathrm{Cl}^{-}>\mathrm{H}_{2} \mathrm{PO}_{4}{ }^{-}$とホフマイスター系列に 従うのに対して, $\left[\mathrm{MA}_{2}(\mathrm{tpp})\right]$ 型では $\mathrm{ClO}_{4}{ }^{-}>\mathrm{NO}_{3}{ }^{-}>$ $\mathrm{H}_{2} \mathrm{PO}_{4}{ }^{-}>\mathrm{Cl}^{-}$とわずかにではあるが錯形成の効果が見ら れた。

\section{$3 \cdot 2$ ジルコニウム $(\mathrm{IV})$ 錯体}

特徵的な応答選択性が観測された $\left[\mathrm{MA}_{2}(\mathrm{tpp})\right]$ 型の中か ら $\mathrm{Zr}$ 錯体を選んで，より詳しい検討を行った。 $\mathrm{Zr}$ 錯体に ついては, $\mathrm{A}: \mathrm{Cl}$ のシス配位単量体 $\left[\mathrm{ZrCl}_{2}(\mathrm{tpp})\right], \mathrm{A}: \mathrm{OH}$ のテトラ- $\mu$-ヒドロキソ中性二量体 $\left[\mathrm{Zr}_{2}(\mathrm{OH})_{4}(\mathrm{tpp})_{2}\right]$, ト リー $\mu$-ヒドロキソ陽イオン性二量体 $\left[\mathrm{Zr}_{2}(\mathrm{OH})_{3}(\mathrm{tpp})_{2}\right]^{+}$の結 晶構造が報告されているのに対して, それらの相互変換の
条件は未解明であったので，クロロベンゼン中及びクロロ ベンゼンー水二相間での反応を検討した ${ }^{53)}$.

クロロベンゼン中でヒドロキソ錯体 $\left[\mathrm{Zr}(\mathrm{OH})_{2}(\mathrm{tpp})\right]$ の 濃度を $10^{-6.3}$ から $10^{-4} \mathrm{~mol} \mathrm{dm}^{-3}$ の範囲で変化させたとこ ろ, 濃度の増加とともにソーレー帯の短波長シフトが観測 された.この変化は次式で表される二量化反応に帰属され る.

$$
2\left[\mathrm{Zr}(\mathrm{OH})_{2}(\mathrm{tpp})\right]=\left[\mathrm{Zr}_{2}(\mathrm{OH})_{4}(\mathrm{tpp})_{2}\right]
$$

次に, ヒドロキソ錯体のクロロベンゼン溶液と 4 種類 の酸水溶液（濃度を $10^{-6.0}$ から $10 \mathrm{~mol} \mathrm{dm}{ }^{-3}$ の範囲で変 化）を反応させたところ，酸の種類によって多様な変化が 観測された．水和の弱い $\mathrm{ClO}_{4}{ }^{-}$や $\mathrm{NO}_{3}{ }^{-}$の場合には低濃度 領域で，より水和の強い $\mathrm{Cl}^{-}$の場合には高濃度領域で，ソ ーレー帯の短波長シフトが観測された。一方，錯形成能力 の高い $\mathrm{CH}_{3} \mathrm{COO}^{-}$の場合には比較的低濃度領域で, その他 のイオンの場合には上述の変化より高い濃度範囲で，ソー レー帯の長波長シフトが観測された．Fig. 9 にそれぞれの 系に固有の波長での吸光度を酸の濃度の対数に対してプロ ットした結果を示す。これらの変化は, 式（８）による陽 イオン性二量体の生成及び式（9）と（10）による中性単 量体の生成に帰属される.

$$
\begin{aligned}
& {\left[\mathrm{Zr}_{2}(\mathrm{OH})_{4}(\mathrm{tpp})_{2}\right]_{\mathrm{o}}+\mathrm{H}^{+}+\mathrm{X}^{-}=}\left(\left[\mathrm{Zr}_{2}(\mathrm{OH})_{3}(\mathrm{tpp})_{2}\right], \mathrm{X}\right)_{\mathrm{o}} \\
&\left(\left[\mathrm{Zr}_{2}(\mathrm{OH})_{3}(\mathrm{tpp})_{2}\right], \mathrm{X}\right)_{\mathrm{o}}+\mathrm{H}^{+}+\mathrm{X}^{-}= \\
& 2([\mathrm{Zr}(\mathrm{OH}) \mathrm{X}(\mathrm{tpp})])_{\circ} \\
&([\mathrm{Zr}(\mathrm{OH}) \mathrm{X}(\mathrm{tpp})])_{\mathrm{o}}+\mathrm{H}^{+}+\mathrm{X}^{-}=\left(\left[\mathrm{ZrX}_{2}(\mathrm{tpp})\right]\right)_{\circ}
\end{aligned}
$$

なお，式（9）及び（10）の反応は接近した濃度範囲で 進行するために，式(11）で表現される.

$$
\begin{aligned}
\left(\left[\mathrm{Zr}_{2}(\mathrm{OH})_{3}(\mathrm{tpp})_{2}\right], \mathrm{X}\right)_{\mathrm{o}}+2 \mathrm{H}^{+}+2 \mathrm{X}^{-}= \\
\left(\left[\mathrm{ZrX}_{2}(\mathrm{tpp})\right]\right)_{\circ}
\end{aligned}
$$

これらの化学種間の関係を Scheme 1 に示す.

以上の知見を元に 4 種の中性錯体及び 3 種の陽イオン 性錯体を単離して，これらをキャリヤーとするイオン選択 電極のアニオン応答を検討した（Fig. 10）。すべての陽イ オン性錯体, $\left[\mathrm{Zr}_{2}(\mathrm{OH})_{3}(\mathrm{tpp})_{2}\right], \mathrm{X}$ は通常の陰イオンに対し てホフマイスター的な応答を示すとともに, 対イオン $\mathrm{x}$ の親油性が高いほど応答は弱く，その応答は純粋なイオン 交換に帰属される.

中性錯体の内で $\left[\mathrm{ZrCl}_{2}(\mathrm{tpp})\right]$ を用いた場合は，電位のド リフトが顕著であった。この錯体は高濃度の塩酸共存下で の久存在する化学種であり, サンプル溶液との接触によっ 
て徐々に加水分解するためと説明される。このとき生成す

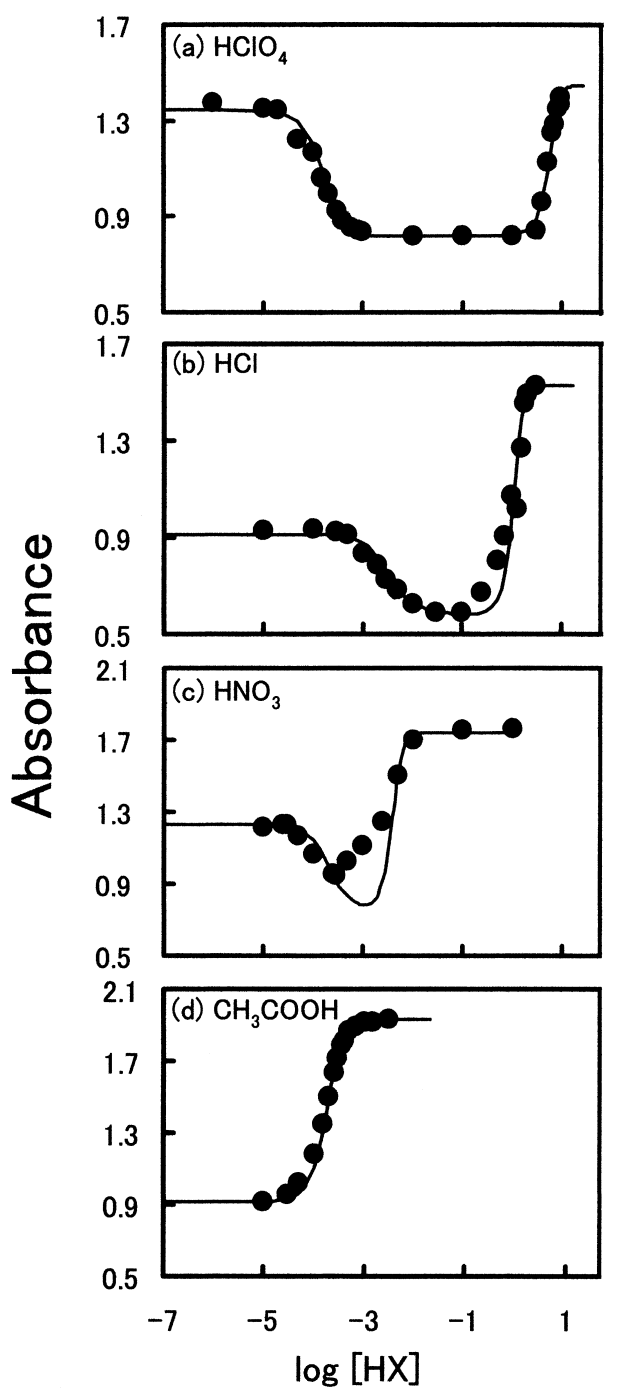

Fig. 9 Changes in absorbance by two-phase reaction of $\left[\mathrm{Zr}_{2}(\mathrm{OH})_{4}(\mathrm{tpp})_{2}\right]$ with acids

$C_{\mathrm{Zr}}=4 \times 10^{-5} \mathrm{M}$. Solid lines were calculated using the constants obtained.
る $[\mathrm{Zr}(\mathrm{OH}) \mathrm{Cl}(\mathrm{tpp})]$ は, 酢酸イオンに対して強い応答を示 したのに対して, $\left[\mathrm{Zr}(\mathrm{OH})_{2}(\mathrm{tpp})\right]$ はほとんど応答を示さな かった。 $\mathrm{Zr}-\mathrm{Cl}$ の結合は比較的弱いために酶酸イオンによ る置換反応が起こるのに対して, Zr-OH の結合は強固で置 換反応が起こりにくい. なお, $[\mathrm{Zr}(\mathrm{OH}) \mathrm{Cl}(\mathrm{tpp})]$ の酢酸イ オンに対する応答も，時間の経過とともに消失した $\{$ Fig. 11 (a) $\}$ 。これは更に加水分解が進んで $\left[\mathrm{Zr}(\mathrm{OH})_{2}(\mathrm{tpp})\right]$ に なるためであり, $1 \mathrm{~mol} \mathrm{dm}^{-3}$ の塩酸溶液中に浸すだけで 応答は復活し，その中で保存すれば少なくとも 1 か月の 間電位応答は持続した $\{\text { Fig. } 11 \text { (b) }\}^{54)}$.

クエン酸に対するこれらのキャリヤーの応答を Fig. 12 に示す．クエン酸は錯形成能力が高く, 陽イオン性錯体の 複核構造を開裂しながら錯形成するために，スーパーネル ンスト応答を示した ${ }^{12)}$. 一方, 中性単量体はいずれもネル ンスト応答を示したが, 中でも $\left[\mathrm{Zr}(\mathrm{OH})_{2}(\mathrm{tpp})\right]$ は他のイ オンに対する応答が弱いのでクエン酸選択性が高い。検出 下限も $10^{-7} \mathrm{~mol} \mathrm{dm}^{-3}$ と低く, ジュース中のクエン酸定 量などに適している.

なお，著者らの研究と平行して，同一の錯体がフッ化物 イオン選択電極のキャリヤーとして提案されている ${ }^{511}$.

$3 \cdot 3$ ニオブ $(V)$ 錯体

単離・構造解析されている $\mathrm{Nb}(\mathrm{V})$ 錯体の中で中性単核 錯体の $[\mathrm{NbOCl}(\mathrm{tpp})]$ は, $\left[\mathrm{ZrCl}_{2}(\mathrm{tpp})\right]$ と同様に加水分解 しやすいので，中性複核錯体の $\left[\mathrm{Nb}_{2} \mathrm{O}_{3}(\mathrm{tpp})_{2}\right]$ を出発物質 として用いた ${ }^{55}$. 酸化数が同じでも, $\mathrm{Nb}(\mathrm{V})$ 錯体の場合に は補助配位子がポルフィリン環に対して同一の側に位置す る点で，先に報告のある $\mathrm{Mo}(\mathrm{V})$ 錯体 $^{50)}$ と構造上の違いが ある。

クロロベンゼン-水二相間で $\mathrm{HClO}_{4}$ 及び $\mathrm{HCl}$ との反応 を検討した。それぞれの系に固有の波長での吸光度を酸の 濃度の対数に対してプロットした結果を Fig. 13 に示す. $\mathrm{HClO}_{4}$ との反応では短波長シフトが観測され，その反応 は式(12)に帰属される.

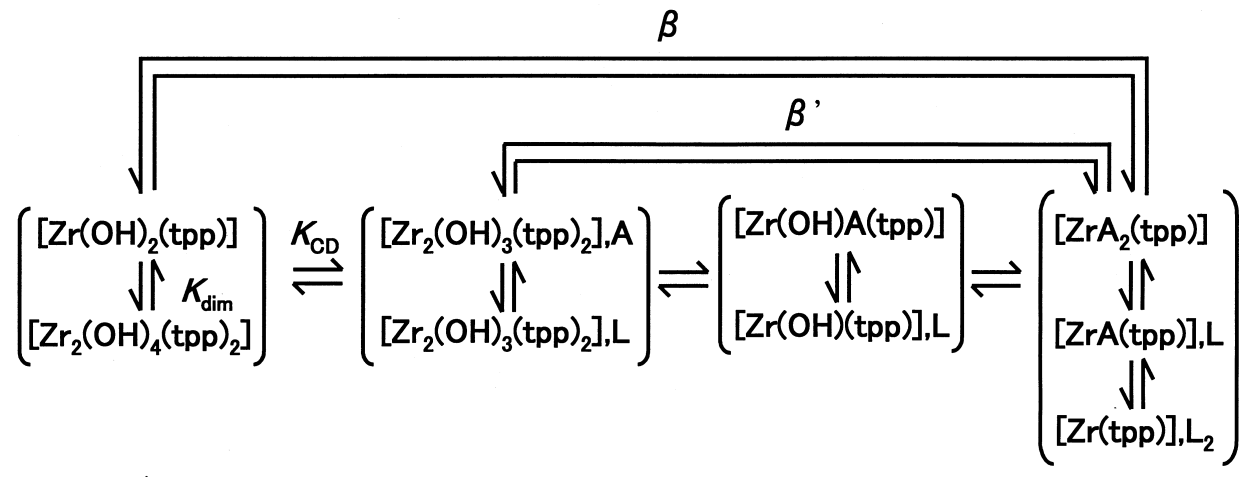

$\mathrm{OH} / \mathrm{Zr}=2$

0

Scheme 1 Relation between Zr-tpp complexes with decrease in hydrolysis degree 

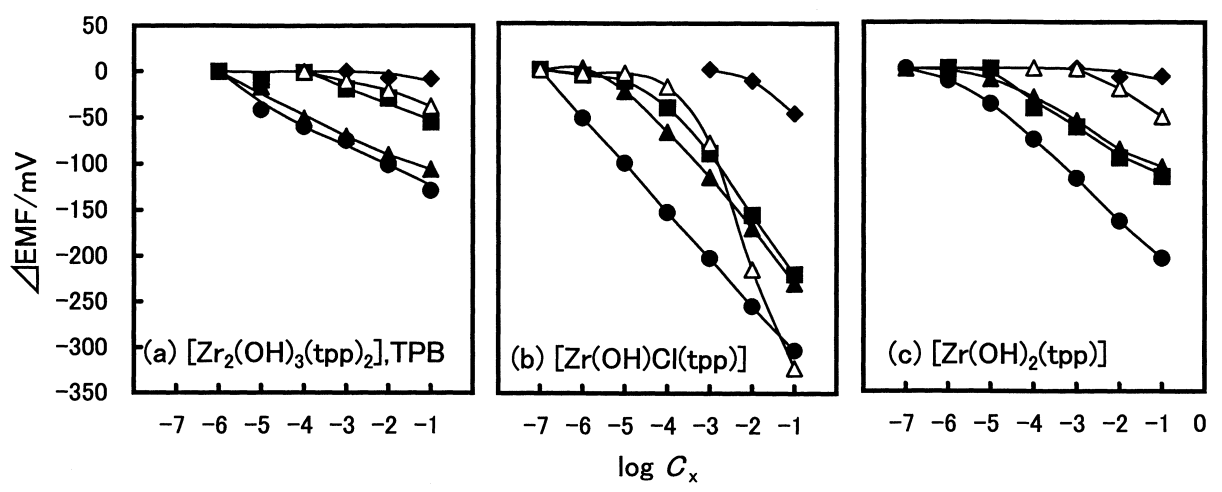

Fig. 10 Potential responses of ISEs using Zr-tpp complexes as carrier to common anions Anion: (\) $\mathrm{ClO}_{4}{ }^{-},(\boldsymbol{\Delta}) \mathrm{SCN}^{-},(\boldsymbol{\square}) \mathrm{NO}_{3}{ }^{-},(\diamond) \mathrm{Cl}^{-},(\triangle)$ acetate. $\mathrm{pH} 3.0$

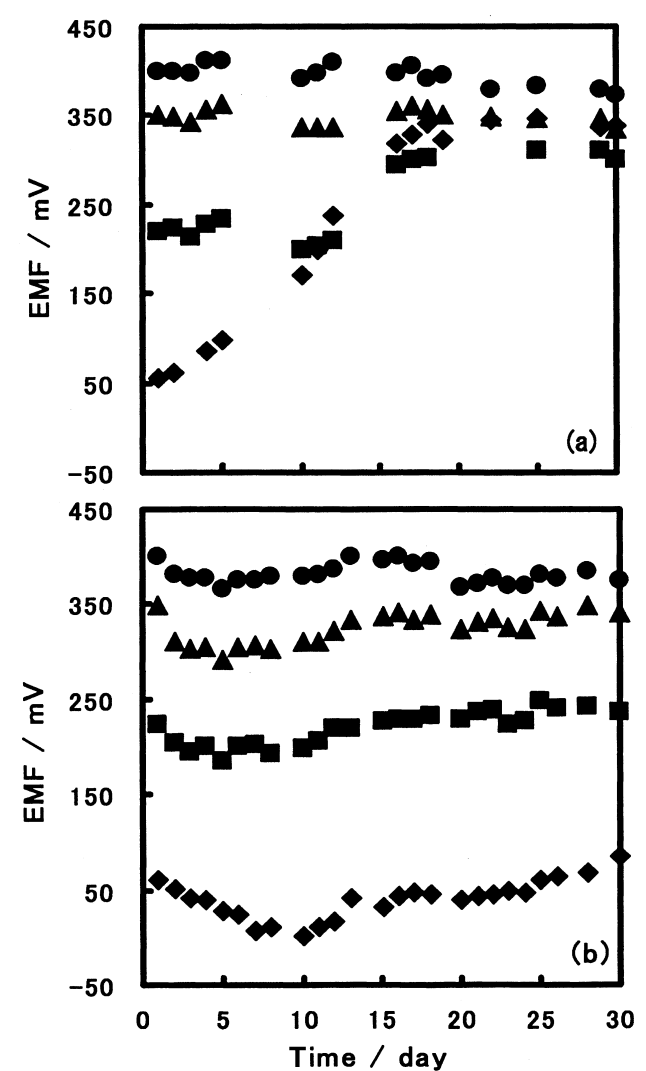

Fig. 11 Effects of storage solutions on change in potential response of $[\mathrm{Zr}(\mathrm{OH}) \mathrm{Cl}(\mathrm{tpp})]$-based ISE to acetate

Storage solution: (a) water, (b) $1 \mathrm{~mol} \mathrm{dm}^{-3} \mathrm{HCl}$. Acetate concentration $/ \mathrm{mol} \mathrm{dm}{ }^{-3}:(\diamond) 10^{-1},(\square)$ $10^{-2},(\mathbf{\Delta}) 10^{-3},(\mathbf{O}) 10^{-4}$

$\left[\mathrm{Nb}_{2} \mathrm{O}_{3}(\operatorname{tpp})_{2}\right]_{\mathrm{o}}+\mathrm{H}^{+}+\mathrm{ClO}_{4}{ }^{-}=$

$$
\left(\left[\mathrm{Nb}_{2} \mathrm{O}_{2}(\mathrm{OH})(\mathrm{tpp})_{2}\right], \mathrm{ClO}_{4}\right)_{\text {。 }}
$$

これに対して $\mathrm{HCl}$ との反応では長波長シフトが観測さ れ，その反応は式(13) に帰属される。

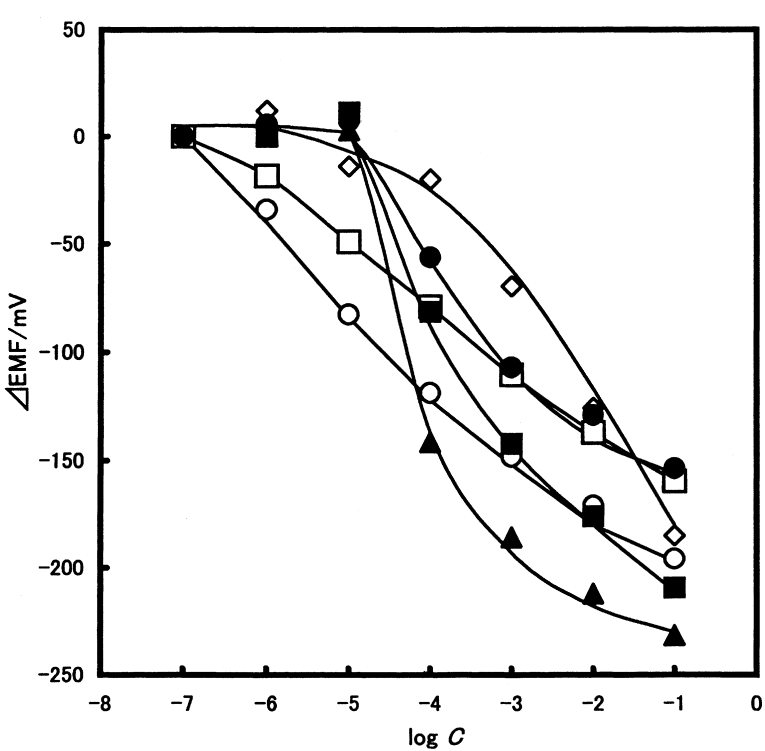

Fig. 12 Potential responses of ISEs using Zr-tpp complexes as carrier to citrate

Carrier: $(\bigcirc)[\mathrm{Zr}(\mathrm{OH}) \mathrm{Cl}(\operatorname{tpp})],(\square)\left[\mathrm{Zr}(\mathrm{OH})_{2}\right.$ (tpp) ], $(\diamond)\left[\mathrm{Zr}\left(\mathrm{CH}_{3} \mathrm{COO}\right)_{2}(\mathrm{tpp})\right],(\mathbf{O})\left[\mathrm{Zr}_{2}(\mathrm{OH})_{3}(\mathrm{tpp})_{2}\right], \mathrm{TPB}$, (兄) $\left[\mathrm{Zr}_{2}(\mathrm{OH})_{3}(\mathrm{tpp})_{2}\right], \mathrm{ClO}_{4},(\boldsymbol{\Delta})\left[\mathrm{Zr}_{2}(\mathrm{OH})_{3}(\mathrm{tpp})_{2}\right], \mathrm{Cl}$. $\mathrm{pH} 3.0$

$$
\begin{aligned}
&\left(\left[\mathrm{Nb}_{2} \mathrm{O}_{3}(\operatorname{tpp})_{2}\right]+2 \mathrm{H}^{+}+2 \mathrm{Cl}^{-}\right.= \\
& 2([\mathrm{NbOCl}(\operatorname{tpp})])_{0}
\end{aligned}
$$

イオン選択電極のキャリヤーとしては, 陽イオン性二量 体がイオン交換的な選択性を示すのに対して, 中性二量体 はほとんど応答を示さなかった。また，中性単量体では加 水分解のために電位のドリフトが顕著であり，いずれも適 さなかった。

しかしながら，中性二量体を有機溶媒に溶解し，ホスゲ ンと反応させると, 次式に従って $\mathrm{HCl}$ との反応と同様の スペクトル変化が観測された。 


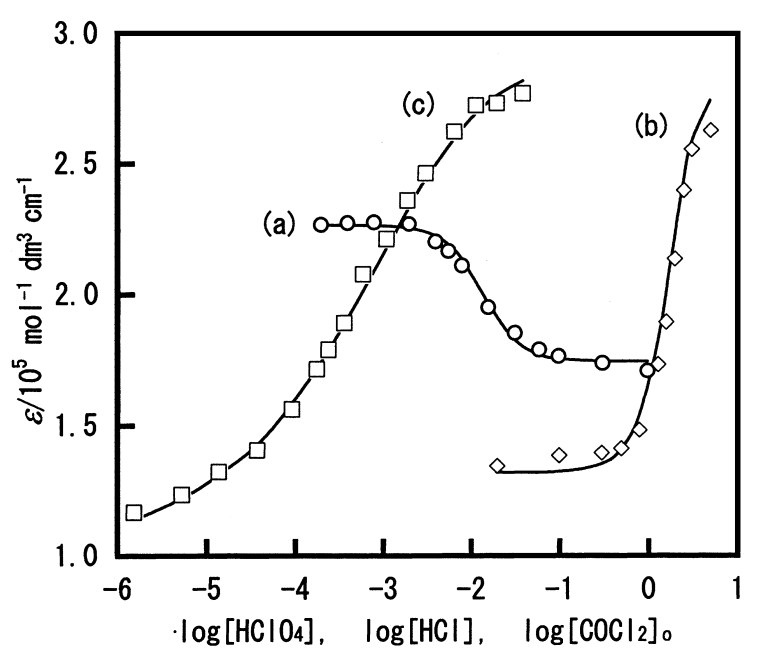

Fig. 13 Changes in molar absorptivity on reactions of $\left[\mathrm{Nb}_{2} \mathrm{O}_{3}(\mathrm{tpp})_{2}\right]$ with $\mathrm{HClO}_{4}(\mathrm{a}), \mathrm{HCl}$ (b), and $\mathrm{COCl}_{2}$ (c)

$C_{\mathrm{Nb}}=5 \times 10^{-5} \mathrm{~mol} \mathrm{dm}^{-3}$; Reaction medium: (a, b) chlorobenzene/water, (c) toluene-chloroform (9:1); $\lambda_{\max } / \mathrm{nm}$ : (a) 418, (b, c) 424. Solid curves were calculated using the constants obtained.

$\left(\left[\mathrm{Nb}_{2} \mathrm{O}_{3}(\mathrm{tpp})_{2}\right]+\left[\mathrm{COCl}_{2}\right]=\right.$

$$
2([\mathrm{NbOCl}(\mathrm{tpp})])_{\mathrm{o}}+\left[\mathrm{CO}_{2}\right]
$$

この反応は迅速であり, 有機溶媒中のホスゲンの定量に 用いることができる (Fig. 13). 幾つかのクロロアルカン が明所及び暗所において分解によりホスゲンを生成する過 程を本法によって追跡した（Fig. 14）. 光によって分解は 加速されるが, 漸近值は同じであり, クロロフォルム $>$ 四

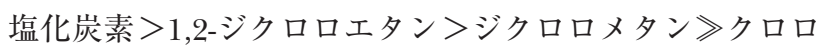
ベンゼンの順であった.

\section{4 その他の高酸化数金属錯体}

\section{$4 \cdot 1$ ジルコニウム (IV) -ドデシルイミノニ酶酸錯体}

ポルフィリンと同様に2-の電荷を供給し，かつ親油性 を有する配位子としてドデシルイミノ二酢酸（ $\mathrm{H}_{2}$ dida） を合成し，そのジルコニウム錯体 $\left[\mathrm{ZrCl}_{2}(\right.$ dida $\left.)\right]$ の性能を 評価した ${ }^{56)}$ ・ ポルフィリン錯体で得られた知見を考慮する と, この錯体も試料溶液との接触によって加水分解され, $\left[\mathrm{Zr}(\mathrm{OH})_{2}(\right.$ dida $\left.)\right]$ あるいはこれが多量化したものに変化し ていると考えられる.

$\mathrm{ClO}_{4}{ }^{-}$や $\mathrm{SCN}^{-}$にはわずかな電位応答（15 mV/decade） を示すのに対して, 比較的高濃度のサリチル酸にはかなり の応答 $(43 \mathrm{mV} /$ decade $)$ を示し, 錯形成の効果が観測さ れた. テトラフェニルホウ酸塩を添加すると検出下限は上 昇してしまうが, 電位応答勾配は $55 \mathrm{mV} /$ decade と改善さ れた。

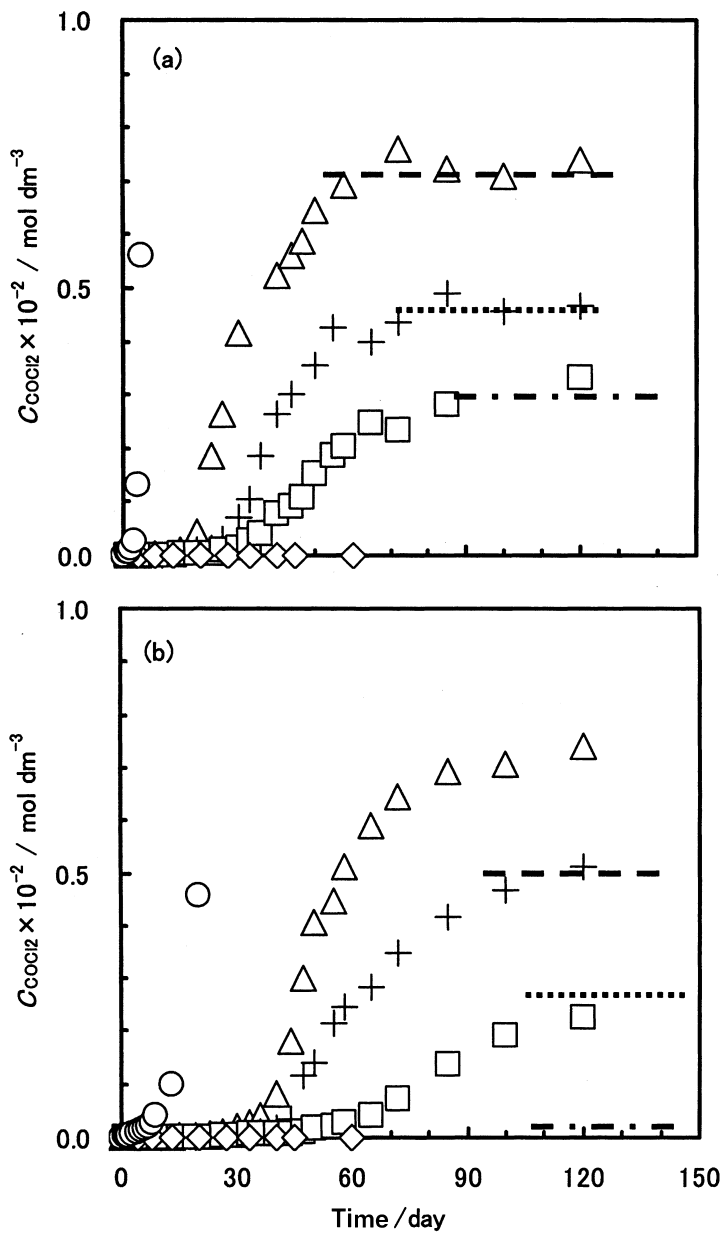

Fig. 14 Time-courses of phosgene formation in chlorinated hydrocarbon in the light (a) and in the dark (b)

Chlorinated hydrocarbon: $(\bigcirc)$ chloroform, $(\triangle)$ carbon tetrachloride, (+) 1,2-dichloroethane, $(\square)$ dichloromethane, $(\diamond)$ chlorobenzene

$4 \cdot 2$ ゲルマニウム (IV) -ニトリロトリフェノール錯体 ポルフィリンとは異なり3-の電荷を供給する配位子と してニトリロトリフェノール $\left(\mathrm{H}_{3} \mathrm{ntp}\right)$ を合成し，そのゲ ルマニウム錯体 $\left[\mathrm{Ge}_{2} \mathrm{O}(\mathrm{ntp})_{2}\right]$ の性能を評価した ${ }^{57)}$.また, 脱プロトン化したフェノールの数の効果を明らかにするた めに，アミノフェノール (Hap) との錯体 $\left[\mathrm{Ge}(\mathrm{ap})_{2} \mathrm{Cl}_{2}\right]$ 及びカテコール $\left(\mathrm{H}_{2} \mathrm{cat}\right)$ との錯体 $\left[\mathrm{Ge}(\mathrm{cat})_{2}\right]$ についても 同様に検討した。

[Ge(ap) $\left.\mathrm{Cl}_{2}\right]$ は $\mathrm{ClO}_{4}{ }^{-}$や $\mathrm{SCN}^{-}$に対してわずかな応答を 示したが，時間経過とともに応答が劣化した。アミノフェ ノールの配位が弱く徐々に解離が起こるためと考えられ る。一方, $\left[\mathrm{Ge}(\mathrm{cat})_{2}\right]$ はどのアニオンに対しても応答を示 さなかった，配位が強すぎて中心の $\mathrm{Ge}(\mathrm{IV})$ が反応性を失 うためと考えられる。

これに対して $\left[\mathrm{Ge}_{2} \mathrm{O}(\mathrm{ntp})_{2}\right]$ はフッ化物と過塩素酸イオ ンに対して $10^{-3} \sim 10^{-1} \mathrm{~mol} \mathrm{dm}{ }^{-3}$ の範囲でかなりの応答 
を示した．塩化トリドデシルアンモニウムを $30 \mathrm{~mol} \%$ 添 加すると, すべての陰イオンに対する応答が強まったが, 特にフッ化物イオンに対する直線応答範囲が $10^{-4} \sim 10^{-1}$ mol dm ${ }^{-3}$ まで改善した.

更に新しい選択性の発現を期待して Ge(IV) 以外の中心 金属として $\operatorname{Sn}(\mathrm{IV})$ や Ti(IV) の導入を試みたが，キャリヤ 一として用いるには安定性が不十分のようである.

\section{$4 \cdot 3 \quad 1$-ナフチルボロン酸}

金属イオンではないが，硬い酸として知られるホウ素を 有する1-ナフチルボロン酸 $\left\{\mathrm{NpB}(\mathrm{OH})_{2}\right\}$ について, キャ リヤーとしての性能を検討した ${ }^{58)}$. 添加塩なしでは全く応 答が得られないが，塩化トリドデシルメチルアンモニウム （C,Cl）を添加すると，フッ化物イオンに対する選択的な 応答が得られた。有機溶媒中での反応の解析を考虑する と, 次式に従って応答すると考えられる。

$$
\left[\mathrm{NpB}(\mathrm{OH})_{2}\right]+3 \mathrm{~F}^{-}+2 \mathrm{H}^{+}+[\mathrm{C}, \mathrm{Cl}]=\left[\mathrm{C}, \mathrm{NpBF}_{3}\right]+\mathrm{Cl}^{-}
$$

5 おわりに

「水和が強く相間移動が不利とされる陰イオンは硬い塩 基であるから，硬いルイス酸をキャリヤーに用いれば新し い選択性が創出できるだろう」という単純な考えで研究を 開始した。当初は, 合成原料に塩化物を用いるので補助配 位子としてクロロ基を含む錯体を想定していたが，精製の 過程あるいはキャリヤーとして使用中に加水分解し, ヒド ロキソ型になっている場合が多いことを確認した，その効 果は以下のとおりである.

(1) $\mathrm{pH}$ 応答が顕著となり, $\mathrm{pH}$ の厳密な制御が必要とな る.

(2)キャリヤーの反応性が低下するので, 選択性の発現 には有効であった。

(3) 塩酸などによるコンディショニングにより製膜した 状態でも反応性を回復できることが明らかになった。

(4) ヒドロキソ基やオキソ基による架橋が起こり陽イオ ン性の錯体を形成する場合には，イオン交換的な応 答機構も寄与するようになる。

(5) 架橋によりサンプルアニオンが複数のルイス酸サイ 卜と相互作用できるような場合には，特異な選択性 が発現することもある.

これらの結果により 1 で述べた幾つかの未解明問題に ついて一つの解答を与えることができた。また，その成果 として $\left[\mathrm{Zr}(\mathrm{OH})_{2}(\mathrm{tpp})\right]$ を用いるクエン酸選択電極を開発 した。

本研究の一部は，文部科学省科学研究費補助金（16550135）の 交付を受けて行われたものである.

\section{文献}

1) P. D. Beer, P. A. Gale: Angew. Chem. Int. Ed., 40, 486 (2001).

2) A. Bianchi, K. Bowman-James, E. Garcia-Espana, "Supramolecular Chemistry of Anions", (1997), (Wiley$\mathrm{VCH})$.

3) P. Buhlmann, E. Pretsch, E. Bakker: Chem. Rev., 98, 1593 (1998).

4) H. A. Badr, M. Diaz, M. F. Hawthorne, L. G. Bachas: Anal. Chem., 71, 1371 (1999).

5) K. Perdikaki, I. Tsagkatakis, N. A. Chaniotakis, R. Altmann, K. Jurkschat, G. Reeske: Anal. Chim. Acta, 467, 197 (2002).

6) M. M. G. Antonisse, B. H. M. Snellink-Ruel, I. Yigit, J. F. J. Engbersen, D. N. Reinhoudt: J. Org. Chem., 62, 9034 (1997).

7) S. Nishizawa, Y. Kato, N. Teramae: J. Am. Chem. Soc., 121, 9463 (1999).

8) K. Fluri, J. Koudelka, W. Simon: Helv. Chim. Acta, 75, 1012 (1992).

9) E. Bakker, E. Malinowska, R. D. Schiller, M. E. Meyerhoff: Talanta, 41, 881 (1994).

10) U. Schaller, E. Bakker, U. E. Spichiger, E. Pretsch: Anal. Chem., 66, 391 (1994).

11) E. Bakker, E. Malinowska, R. D. Schiller, M. E. Meyerhoff: Talanta, 41, 881 (1994).

12) E. D. Steinle, S. Amemiya, P. Buhlmann, M. E. Meyerhoff: Anal. Chem., 72, 5766 (2000).

13) E. Malinowska, J. Niedziolka, E. Rozniecka, M. E. Meyerhoff: J. Electroanal. Chem., 514, 109 (2001).

14) E. Malinowska, J. Niedziolka, M. E. Meyerhoff: Anal. Chim. Acta, 432, 67 (2001).

15) W. Zhang, E. Rozniecka, E. Malinowska, P. Parzuchowski, M. E. Meyerhoff: Anal. Chem., 74, 4548 (2002).

16) Y. Qin, E. Bakker: Anal. Chem., 76, 4379 (2004).

17) T. Sokalski, T. Zwickl, E. Bakker, E. Pretsch: Anal. Chem., 71, 1204 (1999).

18) T. Sokalski, A. Ceresa, M. Fibbioli, T. Zwickl, E. Bakker, E. Pretsch: Anal. Chem., 71, 1210 (1999).

19) S. Daunert, L. G. Bachas: Anal. Chem., 62, 1428 (1990).

20) Y. Tsujimura, T. Sunagawa, M. Yokoyama, K. Kimura: Analyst, 121, 1705 (1996).

21) V. M. Shkinev, B. Ya. Spivakov, G. A. Vorobeva, and Yu. A. Zolotov: Anal. Chim. Acta, 167, 145 (1985).

22) S. A. Glazier, M. A. Arnold: Anal. Chem., 63, 754 (1991).

23) A. Yuchi, S. Kani, T. Suzuki, H. Hattori: Bull. Chem. Soc.Jpn., 76, 971 (2003).

24) K. Fluri, J. Koudelka, W. Simon: Helv. Chim. Acta, 75, 1012 (1992).

25) R. L. DeMeullenaere, P. Onsrud, M. A. Arnold: Electroanalysis, 5, 833 (1993).

26) 鈴木崇嗣，後藤康正，可児真平，湯地昭夫：日本分 析化学会第 52 年会講演要旨集, p. 82 (2003).

27) K. G. Schrantz, L. Nagy, T. Fiore, L. Pellerito, T. Gajda: J. Chem. Soc., Dalton Trans., 2002, 152.

28) 後藤康正，宮崎久美子，服部寛之，湯地昭夫：分析 化学 (Bunseki Kagaku), 52, 707 (2003).

29) P. Schulthess, D. Ammann, W. Simon, C. Caderas, R. Stepanek, B. Krautler: Helv. Chim. Acta, 67, 1026 
(1984).

30) S. Daunert, S. Wallace, A. Florido, L. G. Bachas: Anal. Chem., 63, 1676 (1991).

31) V. K. Gupta, A. K. Jain, L. P. Singh, U. Khurana, P. Kumar: Anal. Chim. Acta, 379, 201 (1999).

32) S. Shahrokhian, A. Hamzehloei, M. Bagherzadeh: Anal. Chem., 74, 3312 (2002).

33) Q. Chang, M. E. Meyerhoff: Anal. Chim. Acta, 186, 81 (1986).

34) N. A. Chaniotakis, A. M. Chasser, M. E. Meyerhoff, J. T. Groves: Anal. Chem., 60, 185 (1988).

35) M. Huser, W. E. Morf, K. Fluri, K. Seiler, P. Schulthess, W. Simon: Helv. Chim. Acta, 73, 1481 (1990).

36) H. Suzuki, H. Nakagawa, M. Mifune, Y. Saito: Anal. Sci., 9, 351 (1993)

37) M. K. Amini, S. Shahrokhian, S. Tangestaninejad: Anal. Chem., 71, 2502 (1999).

38) M. K. Amini, S. Shahrokhian, S. Tangestaninejad: Analyst, 124, 1319 (1999).

39) X.-B. Zhang, C.-C. Guo, L.-X. Jian, G.-L. Shen, R.-Q. Yu: Anal. Chim. Acta, 419, 227 (2000).

40) X.-B. Zhang, C.-C. Guo, L.-X. Jian, G.-L. Shen, R.-Q. Yu: Analyst, 125, 2285 (2000)

41) D. Gao, J.-Z. Li, R.-Q. Yu, G.-D. Zheng: Anal. Chem., 66, 2245 (1994).

42) A. Hodinár, A. Jyo : Chem. Lett., 1988, 993.

43) A. Hodinár, A. Jyo: Anal. Chem., 61, 1169 (1989).

44) E. Malinowska, M. E. Meyerhoff: Anal. Chim. Acta, 300, 33 (1995).
45) E. D. Steinle, U. Schaller, M. E. Meyerhoff: Anal. Sci., 14, 79 (1998).

46) S. B. Park, W. Matuszewski, M. E. Meyerhoff, Y. H. Liu, K. M. Kadish: Electroanalysis, 3, 909 (1991).

47) X.-B. Zhang, C.-C. Guo, J.-B. Xu, G.-L. Shen, R.-Q. Yu: Analyst, 125, 867 (2000).

48) N. A. Chaniotakis, S. B. Park, M. E. Meyerhoff: Anal. Chem., 61, 566 (1989).

49) I. H. A. Badr, M. E. Meyerhoff, S. S. M. Hassan: Anal. Chim. Acta, 321, 11 (1996).

50) H. Abe, E. Kokufuta: Bull. Chem. Soc. Jpn., 63, 1360 (1990).

51) E. Malinowska, L. Gorski, M. E. Meyerhoff: Anal. Chim. Acta, 468, 133 (2002).

52) H. Hattori, S. Komiya, A. Yuchi: Anal. Sci., 17, i1353 (2001).

53) H. Hattori, M. Hoshino, T. Wakii, A. Yuchi: Anal. Chem., 76, 5056 (2004).

54) 後藤康正，脇井友之，星野真弓，服部寛之，湯地 昭夫：日本分析化学会第 53 年会講演要旨集, p. 273 (2004).

55) H. Hattori, N. Kachikawa, A. Yuchi : ITE Lett., 3, 696 (2002).

56) H. Hattori, M. Hoshino, A. Yuchi: Anal. Sci., 17, 1217 (2001)

57) 宇野弘重，鈴木崇嗣，後藤康正，伊藤慎祐，安井 孝志，湯地昭夫：分析化学 (Bunseki Kagaku), 53, 1035 (2004)

58) A. Yuchi, J. Sakurai, A. Tatebe, H. Hattori, H. Wada: Anal. Chim. Acta, 387, 189 (1999).

\section{要 旨}

ルイスの酸塩基反応を利用する陰イオン選択電極の中で特に高酸化数の金属イオンを含むものについて， 著者のグループの研究を中心に解説した。単純なジアルキルスズ (IV) 化合物がリン酸イオンや $\alpha$-ヒドロキ シカルボン酸に対して高い選択性を示すのは，コンディショニング中にこれらのイオンを含む多核の錯体が 生成し，その錯体中では院イオンが二つの Sn(IV) と相互作用するとともにアルキル基によって溶媒から効 果的に遮蔽されるためであることを明らかにした。これにより自己集合的な反応がイオン選択電極でも高い 選択性を誘発する可能性を初めて示した。ジルコニウム (IV)-ポルフィリン錯体のうち，陽イオン性二量体 は通常の陰イオンに対してイオン交換による応答を示すのに対して，中性単量体は配位子交換反応による応 答を示した。中性単量体のカルボン酸応答は，補助配位子としての塩化物イオンが徐々に水酸化物イオンに 置換されることにより弱まるが，塩酸との接触で可逆的に回復する．水酸化物に置換されたキャリヤーはク エン酸に対して高い選択性を示した。 